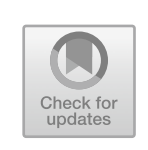

\title{
Stories of Friendship Between the People: "The Relationship Between Two Countries Is Based on the Friendship Between Their People"
}

\section{“GREAT BRothers"}

China and Chile are located far away from each other; however, the two peoples have enjoyed a long history of interactions and profound friendship. Pablo Neruda, a Nobel Prize laureate in literature and a major poet in Chile, referred to China affectionately as a "great brother." Even the names of our two countries, China and Chile, resemble those of two brothers, and our two people have indeed fostered a brotherly relationship.

The two people have a tradition of mutual understanding and affection. Although our two people are separated by the ocean, we admire each other. Neruda paid multiple visits to China and wrote poems such as Cancion de la tierra China and El Viento de la Asia, in which he expressed his love and best wishes for China. His works have been widely read in China, and they have influenced many Chinese poets. Jose Venturelli, a famous artist of Chile, lived in China for years. He learned from the technique of Chinese ink painting and created works such as the rangtze River, which demonstrated his strong attachment to China. These poems and paintings reflect the profound friendship between the two peoples. These Chilean friends established the Chile-China Cultural Association, the first nongovernmental organization committed to developing friendly ties with China in Latin America. The organization has encouraged a great number of visionary 
people to join in the cause of cultivating the China-Chile friendship. In Santiago, there is a Yangtze River Primary School whose name signifies that the China-Chile friendship is as vibrant as the Yangtze River.

- Work Together for a More Promising Future of China-Chile Relations, a signed article on Chilean media (November 22, 2016).

\section{Commentary}

Pablo Neruda, who was born in Parral, Chile, in 1904, was a Chilean contemporary poet. He began to publish his poems at the age of 13. In 1923, his first volume of verse, Crepusculario (Book of Twilights), was published, followed the next year by Veinte Poemas de Amor y una Canción Desesperada (Twenty Love Poems and A Desperate Song). With keen interest in China and Chinese culture, Neruda visited China three times during his life. In 1951, he came to China to award the Lenin Peace Prize to Soong Ching-ling, and during this visit he met literary celebrities such as Mao Dun, Ding Ling, and Ai Qing. In an interview, when he learned that the traditional Chinese character “聶” in his Chinese name is composed of three “耳”, which means ear, he said, "I have three ears, and the third ear is for listening to the sound of the sea."

Jose Venturelli, who was born in Santiago, Chile, in 1924 and died in Beijing in 1988, was a world-renowned master of painting, lithography, and mural painting, and he was also an "envoy" between China and Chile and between China and Latin America. In 1952, he visited Beijing with his wife and daughter by invitation. He was the first well-known Latin American artist to visit China after the founding of new China. As Deputy Secretary-General of the Asia and Pacific Ocean Peace Conference, Venturelli lived in China with his family for 8 years. During his stay in China, he developed deep friendships with Premier Zhou Enlai, artists Xu Beihong and Qi Baishi, and the poet Ai Qing. Venturelli also taught at the Central Academy of Fine Arts, bringing fresh artistic ideas to Chinese students. The Chinese culture also affected his artistic creations, arousing his pursuit of delicate lines and strokes, wide composition and a free use of colors. The paintings Autumnal Rage, Lushan Mountain, and The Courtyard of Beijing all employ traditional Chinese painting skills. The Yangtze River mentioned by Xi Jinping adopts the composition of traditional Chinese 
landscape painting. As his granddaughter Marva put it, "China was vital to Jose Venturelli because it shaped his mind, art and spirit."

China and Chile are located far away from each other; however, the two countries enjoy a long history of interactions and profound friendship. Early in 1952, Neruda, Venturelli, statesman Salvador Allende, and some other Chilean friends established the Chile-China Cultural Association, the first nongovernmental organization committed to developing friendly ties with China in Latin America. Today, Chile, which has a population of only approximately 16 million, has two Confucius Institutes and more than 20 Chinese language teaching centers. The Latin American Center of the Confucius Institute is located in Santiago, the capital of Chile. The Yangtze River Primary School, mentioned by Xi Jinping, is situated in La Reina, Santiago. The school was officially granted the name in 1987, and it began to pioneer the teaching of the Chinese language in primary school in 2008 .

$\mathrm{Xi}$ had been to Chile in 2001. As he set foot on the beautiful soil of Chile again in 2016, he said, "I feel very much at home and begin my visit with great expectations." Just as he said in an article, "Even the names of our two countries, China and Chile, resemble those of two brothers and our two peoples have indeed fostered a brotherly relationship." He also recollected the "firsts" that have been achieved in the bilateral ties between the two countries: Chile is the first country in South America to establish diplomatic ties with new China, and it is the first Latin American country to sign a bilateral agreement with China on its WTO accession, to recognize China as a full market economy and to sign a bilateral Free Trade Agreement with China. Due to the concerted efforts of the two peoples, the two countries' bilateral ties have grown from strength to strength and yielded fruitful results that are "as vibrant as the Yangtze River." We also learn from the article that China Construction Bank opened a branch in Chile and became the first RMB settlement bank in Latin America, procuring another "first" for our relations, and China has become Chile's largest trading partner and its largest export market for products such as copper, cherries, blueberries, seafood, and wine. Former Chilean Ambassador to China, Fernando Reyes Matta said, "President Xi impressed us deeply with a string of firsts." In his visit to Chile, $\mathrm{Xi}$ cited this Latin American proverb: "A true friend can touch your heart from the other end of the world." This proverb aptly describes the "old-time" and "present-day" friendship between China and Chile. 


\section{“A BOND OF GOLD AND JADE"}

The Chinese people like to refer to a good relationship as "a bond of gold and jade." The gold medals for 2008 Olympic Games in Beijing were made of gold from Chile and jade from China. These medals are symbols of the brotherly relationship between the Chinese and Chilean people.

- Work Together for a More Promising Future of China-Chile Relations, a signed article on Chilean media (November 22, 2016).

\section{Commentary}

In A Dream of Red Mansions, one of China's Four Great Classical Novels, Xue Baochai's gold lock and Jia Baoyu's Precious Jade of Spiritual Understanding were collectively referred to as the symbol of "a bond of gold and jade", which embodies predestined affinity.

The gold medals for the Beijing 2008 Olympic Games employ the design of "gold inlaid with jade" to express the Chinese people's tribute to the Olympic spirit and praise for the athletes. By integrating this element of Chinese culture, this pioneering and novel design broke through the tradition of a single material design for Olympic medals. The "gold inlaid with jade" medals linked China and Chile once again: the jade integrated by 6,000 gold, silver, and copper medals was Kunlun Jade, and the metals inlaid with the jade were all supplied by the world's largest mining giant BHP Billiton's mineral enterprise in Chile. The world's largest open-pit copper mine, the Escondida Copper Mine, provided the $13.04 \mathrm{~kg}$ of gold needed for the gold medals from its copper-bearing gold concentrate; Cannington Silver and Lead Mine provided 1.34 tons of silver to make the gold and silver medals; and Spence Copper Mine provided 6.93 tons of electrolytic copper for the copper and memorial medals. Chile is the world's largest copper exporter and China is the largest importer of Chilean copper, which imports $40 \%$ of its copper from Chile. The data from the Chilean Copper Commission suggests that, in 2014, China imported 2.2 million tons of copper from Chile, which is equivalent to 39\% of Chile's copper exports.

Today, China and Chile are increasingly close in economic and trade activities. China has become Chile's largest trading partner and its largest export market, and Chile has become China's third largest trading partner 
in Latin America, second largest source of fresh fruit import, third largest wine importer, and seventh largest seafood importer. Since the bilateral Free Trade Agreement that was signed in 2006 entered into force, our bilateral trade has grown rapidly, with the bilateral trade volume reaching 31.8 billion US dollars in 2015, which is nearly fourfolds of 8 billion US dollars in 2005. Today, Chinese brands are at the top of the list in the Chilean market, and wine, salmon, and blueberries, cherries, grapes, and other edible fruits are now preferred by Chinese consumers.

In an article on the Chilean media, Xi Jinping took the medal of the Beijing Olympic Games as an example and expounded upon the "bond of gold and jade" between the Chinese and Chilean people. The medals made of Chilean gold and Chinese jade are a metaphor for Xi's profound assessment: China-Chile ties have enjoyed long-term stable growth because both sides are committed to treating each other as equals with mutual respect and trust and leveraging mutual complementarity for win-win outcomes. More importantly, both sides have kept up with the times and made pioneering efforts to push bilateral relations to new highs.

Geographically, Chile is farthest from China. However, Xi Jinping said, "If you have a friend afar who knows your heart, distance cannot keep you two apart." Now the Pacific Ocean can no longer keep China and Chile apart. Instead, the relationship serves as a bond or a bridge linking our two countries. In talks with Chilean President Michelle Bachelet, citing a high level of mutual political trust between our countries, our mutually beneficial and win-win economies, and increasingly closer multilateral cooperation, Xi said China-Chile ties have entered a new era of maturity and stability. During the visit, the two presidents agreed to lift the bilateral ties to a comprehensive strategic partnership, which marked the lift of the strategic coordination and the beginning of more in-depth and comprehensive development between the two countries.

\section{The Century-Old Story of Sociedad Central de BenEFICENCIA CHINA}

Peru and China are "neighbors" connected by the Pacific Ocean. The exchanges between our two peoples began more than 400 years ago. For years, the overseas Chinese living in Peru, together with the Peruvian people, shared weal and woe and strove for self-improvement by making arduous efforts, which made important contributions to the local economic and social development. Sociedad Central de Beneficencia China, which was 
established 130 years ago, also made a positive contribution in promoting the development of the relationship between China and Peru. As far as I know, at present, Peru has approximately 2.5 million Chinese Peruvians, who are of Chinese descent. The Spanish word "paisano" refers specifically to Chinese descendants in Peru, and "chifa", a word that originated from the Cantonese dialect for "having meals", has become the term the Peruvians use to refer to Chinese restaurants. The family-like friendship between our two nations has also taken root and sprouted in the heart of our two peoples.

- Sailing Forward to Build A Bright Future of China-Latin America Relations-Speech at the Peruvian Congress (November 21, 2016).

\section{Commentary}

In 1884, the government of the Qing Dynasty sent Ambassador Zheng Zaoru, Director of the Imperial Entertainment Count, to the US, Spain, and Peru. After arriving in Peru, he learned that there were between 60,000 and 70,000 Chinese who had arrived in Peru approximately 40 years ago and who were distributed throughout Peru. In hope of establishing contact among all Chinese living in Peru, to protect their interests and carry out various charity efforts, he established Sociedad Central De Beneficencia China in 1886 in the hope of "promoting commercial intercourse and benefiting industrialists and businessmen, for the betterment of the Chinese people and Chinese association in Peru." Going through all kinds of hardships and difficulties over the past 130 years, Sociedad Central de Beneficencia China has become the oldest and most influential nation-wide overseas Chinese organization in Peru.

In adherence to the three aims of "promoting commercial intercourse and benefiting industrialists and businessmen, unselfishly helping other peers, and valuing comradeship," this organization has been making an important contribution in uniting the Chinese in Peru, promoting China-Peru friendship, and supporting the development of the motherland. In the mid-nineteenth century, a group of Chinese from Fujian, Guangdong and other places in China traveled across the sea to Peru. They undertook heavy tasks in railway construction and mining work and lived a tough life in Peru. This being the case, Sociedad Central de Beneficencia China raised 
funds in Peru to help them mitigate the difficulties and anxiety and provide financial assistance to the poor and old compatriots with no money to return home. At the same time, they established a Shelter for Chinese from Peru in Guangzhou to shelter older Chinese returning to China from Peru.

During the Chinese People's War of Resistance against Japanese Aggression, the Chinese in Peru were gripped by the warfare in their motherland. Sociedad Central de Beneficencia China set up the Fundraising Federation of Chinese in Peru for Resistance against Japanese aggression jointly with compatriots in Peru, with branches established throughout Peru. They organized the Chinese there to donate money and organize charity bazaars to give support to their homeland, raising 1 million US dollars for the fight within under 2 years. Zhou Enlai once praised them as follows: "The 6,000 Chinese 10,000 miles away, who contributed up to 2 million soles, are a good example for all overseas Chinese and a feather in our cap."

Today, Sociedad Central de Beneficencia China builds on past merits and forges ahead to keep their century-old "signboard" shining. It not only often assists and cooperates with the Chinese Embassy in Peru and the domestic units involved in overseas Chinese affairs in holding various seminars, celebrations, and galas but it also helps local police promote the relationship between the police and civilians and its fundraising committee organizes annually to donate to the nation-wide TV fundraising programs of Peru in the name of the Chinese. These benevolent actions have served as a bridge between the two peoples in promoting friendly exchanges and mutual understanding, which has been well received by those from all walks of life in the two nations. Due to the contributions it has made, Sociedad Central de Beneficencia China was honored with the title of "The Light of Overseas Chinese Associations" at The Eighth Conference for Friendship of Overseas Chinese Associations held in Beijing in June 2016.

The vast Pacific cannot block the deep friendship between the Chinese and Peruvian peoples. The year 2016 marked the 45th anniversary of the establishment of diplomatic relations between China and Peru. On such an important occasion, Xi Jinping related the history of Sociedad Central de Beneficencia China and the century-old friendship between the two peoples at the Peruvian Congress to demonstrate that "the family-like affinity between the two nations" is deeply rooted in history.

"Distance cannot separate true friends who feel so close even when they are thousands of miles apart." Peru, which is known as "the eagle of the Andes", was one of the first Latin American countries to have Chinese 
immigrants, establishing diplomatic relations with new China and carrying out economic and trade exchanges with China. Just 2 months before Xi Jinping's visit to Peru, Kuczynski, who had just assumed the presidency of Peru, made a state visit to China, which was his first official visit after his inauguration as president. The two heads of state exchanging visits within 2 months also set a new record in the history of bilateral exchanges between the two nations. Vice President Mercedes Aráoz of Peru noted with emotion that, "President Xi's visit to Peru is of great significance and will surely elevate the bilateral relations to a new height." Before the speech, Xi was awarded the Grand-Cross Medal of Honor of the Peruvian Congress. This indirectly proved that the bilateral relations between China and Peru have rapidly progressed in a positive direction.

\section{“Chinese People's Two Old Friends" from Peru}

We Chinese believe that "the pleasure of life lies in having close friends." Chinese and Peruvian people find it easy to connect and communicate. This calls to mind two Peruvian friends. One is Antonio Fernandez Arce, a late Peruvian writer and journalist who has had made frequent trips between China and Peru to present a real picture of China to the Latin American people since the 1960s. His daughter, Flor de Maria Fernandez, was born in Beijing in 1970; however, unfortunately, she suffered from severe blood poisoning. Learning this, then-Chinese-Premier Zhou Enlai immediately ordered medical experts to attend to the baby, and the People's Liberation Army responded immediately by organizing soldiers to donate blood to her. Eventually, Flor de Maria Fernandez made it through the crisis. After growing up, she followed in her father's footsteps, devoting her energy to the cause of friendship between the two nations in the long term.

Another friend, Mr. Guillermo Da Ino Ribatto, a Peruvian Sinologist and translator. He taught Spanish at China's Nanjing University and at the University of International Business and Economics from 1979 to 1991, producing works such as Reports from China, Selected Poems of Li Bai, and Encyclopedia of Chinese Culture. In addition, he took part in 25 movies in China, such as The Great Decisive War and Chongqing Negotiations, which was well received by Chinese audiences. Today, he is 87 years old. I heard that he still insists on visiting China every year. I pay high tribute to him.

- Sailing Forward to Build A Bright Future of China-Latin America Relations-Speech at the Peruvian Congress (November 21, 2016). 


\section{Commentary}

Antonio Fernandez Arce, "an old friend of the Chinese people," was a Peruvian journalist and writer. Born in Trujillo, a city in northern Peru, in 1931, Arce was honored as president of the Journalists' Association of Peru at the age of 25, and he has successively served as editor in chief of several well-known newspapers in Peru.

Arce has long been concerned with the changes in and development of China, and he has published many articles on new China in newspapers and periodicals. He came to China with his wife in 1967 to work for the Beijing Broadcasting Station, and their daughter Flor de Maria Fernandez was born 3 years later. However, his newborn daughter suffered from severe blood poisoning and was soon in critical condition. Upon learning this, then-Chinese-Premier Zhou Enlai immediately ordered the best doctors in the People's Liberation Army to attend to the baby. At that time, Flor de Maria Fernandez had to be given a massive blood transfusion. However, the hospital did not have sufficient plasma that matched her blood type. In this urgent case, the medical authority quickly sought help from the garrison troops in Beijing, and soldiers rushed to the hospital to donate blood once after they were informed of the situation. Thanks to the Chinese soldiers who donated blood to help save her, Flor de Maria Fernandez eventually survived.

Arce also acted as a "special envoy" that promoted the establishment of the diplomatic relations between China and Peru. Around 1970, he conveyed China's willingness to further develop friendship with Peru and delivered China' concrete ideas of building diplomatic ties with Peru to Peru's authorities when he returned to Peru to visit his sick father. Later, the communication between China and Peru was facilitated through Arce's help, and China forged diplomatic relations with Peru on November 2, 1971. In 1983, he returned to China as a Spanish expert in the International Department of the Xinhua News Agency. He contributed many articles on China to the newspapers in Latin America and Spain.

Guillermo Da Ino Ribatto is a Peruvian Sinologist who is almost 90 years old but still sowing the seeds of Chinese culture. His predestined affinity with China took root in 1979 when he, as a Professor of linguistics and literature from the National University of San Marcos of Peru, gave lectures to 15 Spanish teachers at the invitation of Nanjing University. Beyond this, he also played the roles of "movie star" and "poet". He appeared in 
25 Chinese movies, including The Great Decisive War, Chongqing Negotiations and Mao Zedong and Snow, during more than 20 years in China, and translated nine collections of poetry of the Tang Dynasty within 9 years, becoming one of the Latin American Sinologists who translated most poets of Tang. Additionally, he published multiple books on Chinese history and culture such as Dragon Carving-Anthology of Ancient Chinese Poetry, Hard-working Bee-1000 Idioms, Proverbs, and Two-part Allegorical Sayings, and Encyclopedia of Chinese Culture.

In a speech at the Congress of Peru, Xi Jinping told a touching story of two Peruvians, which illustrated that "the Chinese and Peruvian peoples are always connected emotionally, and they have always communicated well with each other" and that the two countries, whose hearts are closely linked, form a "community of common destiny." The friendship between countries definitely springs from the people and burgeons through communication. In the 1990s, Xi had visited Peru. When he revisited the land more than 20 years later, he expressed the China-Peru friendship in terms of three "goods"- "good brothers who trust each other," "good partners who pursue common development," and "good friends who shoulder responsibilities together." "The real happiness lies in the passion to keep expanding." He also quoted this famous saying of the Peruvian writer Rivero in his speech to express his hope that the people of the two countries would cooperate sincerely toward realizing their dreams. Peru is striving for "a just, fair and united Peru" by 2021, the 200th anniversary of its independence. By then, China will have built a moderately prosperous society in all respects, reaching the first goal of its "Two Centenary Goals". Xi Jinping combined the aims of the two countries precisely because he expects that the two people will "march forward shoulder-to-shoulder and reach their dreams hand in hand."

\section{The Freedom Fighters Singing Revolutionary Songs}

China and Zimbabwe, in spite of the vast distance between them, have maintained a traditional friendship that is deep and firm. During the struggle for national liberation in Zimbabwe, the Chinese people steadfastly stood behind the Zimbabwean people as comrades-in-arms. I was touched to learn that many Zimbabwean freedom fighters who received training from the Chinese side both in China and at the Nachingwea camp in Tanzania still sing songs such as the Three Rules of Discipline and the Eight Points for Attention. 
- Let the Sino-Zim Flower Bloom with New Splendor, a signed article on Zimbabwe media (November 30, 2015).

\section{Commentary}

The song, Three Rules of Discipline and the Eight Points for Attention, is honored as "the best and most famous Red Song", which has been popular for a long time and can be heard on many occasions. The formulation and development of the Three Rules of Discipline and the Eight Points for Attention praised in the song span a total of 20 years, from October 1927, when the three rules of discipline were proposed in the Sanwan Reorganization, through the corresponding period of 1947, upon the issuing of On the Reissue of the Three Main Rules of Discipline and Eight Points for Attention-Instruction of The General Headquarters of The Chinese People's Liberation Army. The Three Rules of Discipline and the Eight Points for Attention were an important guarantee for the implementation of the party's agenda, guidelines, policies, and tasks, and they served as an important factor in maintaining the combat effectiveness of the army. They have played an important role in strengthening our armed forces, maintaining a close relationship between the army and the people, strengthening the unity between officers and soldiers, and securing the victory of the revolutionary war.

"Heighten our sense of discipline, and we will be invincible in the revolutionary war." As a famous military song of the people's army, the Three Rules of Discipline and the Eight Points for Attention was mentioned in the work of American journalists Snow, Smedley, and Salisbury. When Snow was conducting interviews in Yuwang County, Gansu Province, he heard the song sung by Xu Haidong and the Fifteenth Army of the Red Army headed by $\mathrm{Xu}$, and from this song, he became aware of the critical reason why the Kuomintang army could not defeat the Red Army. The Red Army immediately triggered panic among the people when it arrived in northern Shaanxi. However, only a few months later, the local people began to affectionately refer to them as "our army". The "iron discipline, iron army and iron fighting strength" lodged itself in the public mind along with the song.

The Zimbabwean people are familiar with this Chinese military song because in the 1960s, China offered unselfish assistance to Zimbabwe during its struggle for national independence and liberation. There was a group 
of soldiers in Zimbabwe's "liberation army" who received Chinese military training, during which they not only acquired Chinese military strategies and tactics but also learned the Chinese revolutionary songs and caught the spirit of the Chinese revolutionaries. According to the Zimbabwean philologist Peng Weini, the Three Rules of Discipline and the Eight Points for Attention was the most widely circulated revolutionary song in the army, and it greatly bolstered military morale, enhanced the cohesion of the army, and broadly united the masses.

China and Zimbabwe established diplomatic relations on April 18, 1980, the day of independence of the Republic of Zimbabwe. Since then, the two countries have shown understanding and support for each other and helped each other; therefore, the friendly and cooperative relationship between them has developed smoothly and steadily, and fruitful results have been achieved in bilateral practical cooperation. This makes the China-Zimbabwe relationship a model of China-Africa solidarity and cooperation.

In December 2015, Xi Jinping paid his first state visit to Zimbabwe. In the article he published upon his departure, he mentioned that some Zimbabwean soldiers could still sing the song Three Rules of Discipline and the Eight Points for Attention and recalled that the Chinese people steadfastly stood behind the Zimbabwean people as comrades-in-arms during the national liberation struggle in Zimbabwe. His aim was to demonstrate that China and Zimbabwe enjoy a long-standing and strong friendship and to make clear that China would never forget its old friends.

To look back on history is to look toward the future. "China and Zimbabwe should not only be good friends in politics but also good partners in development," said Xi, adding that they, as "true all-weather friends," they should translate their time-honored friendship into a stronger impetus for bilateral practical cooperation to achieve common development and prosperity. As Xi noted, "Our friendship is rooted in the cultural traditions of our two countries that value sincerity and friendship, in the basic principles of independence and mutual respect to which we both adhere in conducting foreign relations, and in the common mission of our two countries to grow our economy and improve people's livelihood."

\section{A Chinese Mothers' Group- "Love of AfricA"}

The China-Zimbabwe friendship has also taken root and sprouted in the heart of our two people. I know there is a Chinese mothers' group in Zimbabwe called "Love of Africa", and there is a "Father Cheng" from China 
who is so close with the local community that even his car's license plate number is remembered by the kids there. Over the years, they have brought care and warmth to local orphans. Such concrete actions are manifestations of the China-Zimbabwe friendship of the current generation and sow the seeds of friendship for future generations.

- Let the Sino-Zim Flower Bloom with New Splendor, a signed article on Zimbabwe media (November 30, 2015).

\section{Commentary}

There is a Chinese mothers' group in Zimbabwe called "Love of Africa", which is known far and wide. The mothers donate money and supply to local orphanages, seek medicine from thousands of miles away for the orphans, and provide spiritual comfort for the orphans. Statistics show that the number of Zimbabwean orphans, which has continued to grow, now stands at approximately 1.8 million. They were abandoned by their parents, or their parents died early. Many even suffer from AIDS. Some lucky ones have been assigned to orphanages by the Social Welfare Bureau, and there are still many orphans who are homeless. Because of the country's limited economic and social development, most of the orphanages in Zimbabwe have a serious shortage of funds.

On April 10,2014, to give aid to the orphans, Peng Yan and some other Chinese mothers living in Zimbabwe decided to establish a nonprofit organization. They gave the organization a positive name- "Love of Africa", and its Chinese name means "must love".

After its founding, "Love of Africa" selected a group of needy orphanages to which to provide assistance. In addition to making donations to them, they raise tuition fees for the orphans. Sowing the seeds of love on the continent of Africa, the mothers care for the orphans with selfless "Father Cheng". Their philanthropic actions have touched many people. Lindy, the Financial Manager of a local orphanage, expressed her gratitude to the members of "Love of Africa" for their unselfish help, saying, "I have never seen a kind person like them. Never before. They paid the children's tuition, brought them new mattresses, and bought food for them... It is hard for us to keep the orphanage running without the help from the Chinese mothers." 
In an article published on the Zimbabwe media, Xi Jinping told the moving story of "Love of Africa". The local mainstream newspaper The Sunday Mail titled the article by Xi Jinping "From China, with Love". The editor of the newspaper later said in an interview that this title was derived from "my true feeling after reading the article."

In the article, Xi Jinping also included two sayings. One was from Zimbabwe, "Chikuni chimwe hachikodzi sadza," meaning that one is unable to cook corn porridge with only one piece of firewood and the other is a Chinese saying, "When everybody adds firewood, the flames will rise high." It can be said that the China-Africa friendship lays a solid foundation for the development of China-Africa relations. As Xi stated in the keynote speech delivered at the opening ceremony of the Second China-Africa People's Forum, "Now more and more ordinary people are becoming directly involved in China-Africa cooperation and exchanges, accompanied by higher and higher expectations of the development of China-Africa relations from both the Chinese and African people. Therefore, we should actively create conditions for more Chinese and African people to enjoy the increasingly fruitful results achieved in China-Africa cooperation to further consolidate public support for cooperation."

\section{Never Forget Professor Colin Mackerras}

I am delighted to see that Emeritus Professor Colin Mackerras of Griffith University is with us today. In 1964, Professor Mackerras went to China for the first time. Over the past five decades, he has visited China over 60 times, and he has made tireless efforts to present a real China to Australia and the world based on his personal experience of China's development and progress. It is worth mentioning that his son Stephen is the first Australian national born in China since the founding of the People's Republic in 1949. With his unremitting efforts and devotion, Professor Mackerras has built a bridge of mutual understanding and amity between our people. In September of this year, he was conferred the Friendship Award by the Chinese government. Professor Mackerras, I wish to express deep appreciation to both you and many other Australians for what you have done to enhance the friendship between our two nations.

- Jointly Pursue the Dream of Development for China and Australia and Realize Prosperity and Stability in Our Region-Speech at the Parliament of Australia (November 17, 2014). 


\section{Commentary}

Colin Mackerras was born in Sydney in 1939. He started his Sinology research career during the 1950s and 1960s. After graduating from the University of Melbourne, he went on to study at the University of Cambridge in England. In 1964, when Australia had not yet established diplomatic relations with China, Mackerras, who had just graduated, along with his wife, offered to teach in China, and they had their eldest son Stephen in the country. The boy, who was born in February 1965, was the first Australian citizen born in the People's Republic of China. Today, that young scholar has now become a well-known China watcher, with many works to his credit. Professor Mackerras serves as an Emeritus Professor at Griffith University, the Australian-side Director of the Tourism Confucius Institute of Griffith University, and an Academician of the Australian Academy of the Humanities. With his love of China, he primarily focuses his research on the Chinese culture and China-Australia relations. Following Chinese drama with interest, he published The Rise of the Peking Opera and Chinese Drama: A Historical Survey. Studying China's ethnic minorities, he demonstrated profound knowledge and penetrating insight in China's Ethnic Minorities and Globalization as well as China's Minority Cultures, Identities, and Integration Since 1912. His works on Chinese history include The New Cambridge Handbook of Contemporary China and China in My Eyes: Western Images of China Since 1949. "It was my mother who influenced me to make the decision to come to China. But when I lived in China, it also influenced me like a mother," said Mackerras.

As an envoy for China-Australia friendship, Mackerras visited China over 60 times to attend academic conferences as a scholar or for tourism, communication or onsite investigation. He has also taught at Renmin University of China and Beijing Foreign Studies University many times. For decades, he traveled between China and Australia and made tireless efforts to present a real China to Australia and the world. In China in My Eyes: Western Images of China Since 1949 published in 2013, he conducted a systematic review of the West's views and understandings of China since the founding of new China and forayed deeply into the political, economic, cultural, and other factors that have affected China's many images'. This book was well received by sinologists.

The stories of old friends should be passed down through generations, and the stories of making new friends should be told to the world. By telling 
the story of Professor Mackerras at the Parliament of Australia, Xi Jinping illustrated the idea in a vivid way-the bridge of mutual understanding and amity between countries must be developed jointly by a group of individuals who promote international friendship.

"The Chinese people will never forget any friend." Xi Jinping proved this with practical actions on diplomatic occasions. When more than 3,000 people from all walks of life from Japan and those friendly to China visited our country, he sat with them and discussed the old days with old friends to encourage China-Japan friendship; when he paid a state visit to India, he arranged a special meeting with the sister of Doctor Dwarkanath Kotnis, moving her to say that the Chinese government and the Chinese people still remember Dwarkanath Kotnis and his family; and in his visit to Egypt, he met with the Arab friends who received the Award for Outstanding Contribution to China-Arab Friendship, including Boutros-Ghali, the former United Nations Secretary-General. In June of 2014, Xi announced the Chinese government's decision to establish the Five Principles of Peaceful Coexistence Friendship Award, with the aim of engaging new friends to play an exemplary role in inheriting the spirit of the Five Principles of Peaceful Coexistence.

\section{A Brazilian with a Chinese Heart}

Carlos Tavares is an old man from Brazil. He has said that he is "a Brazilian with a Chinese heart." In the past 40 years, he has tirelessly engaged in studies in China, writing eight books and over 500 articles on China and delivering hundreds of speeches on the country. His writings guide many Brazilians to learn about China and to feel closer to China. When someone asked him what motivated him to do this, he said, "Nothing. I just want to introduce China to more people."

This touching story is a beautiful wave in the long river of China-Latin America friendship. Thanks to the contributions of a stream of Chinese and Latin American friends, the long river flows nonstop day and night like the Yangtze and Amazon Rivers.

- Carry Forward Traditional Friendship and Jointly Open up New Chapter of Cooperation-Speech at the National Congress of Brazil (July 16, 2014). 


\section{Commentary}

When Chinese journalists assume a post in Brazil, many will be given the following advice: if you have questions about Brazil's past and present, go to the China scholar, Carlos Tavares; if you have questions about China's past and present, go to Carlos Tavares.

As an old man having reached 90, Tavares has been observing and studying China for more than 40 years. He began his career in 1971, when his first long report on China was published in O Globo, a Brazilian newspaper. In 1972, he risked his life to receive a delegation from China during the special period when China and Brazil had not yet established diplomatic relations and Brazil was under the dictatorship of the military government. In 1990, the Brazilian media released an exclusive interview with him in which he said that he was "a Brazilian with a Chinese heart." Having been awarded the China-Latin America and Caribbean Friendship Medal by the China-Latin America and Caribbean Friendship Association and the Brazilian National Federation of Commerce in 2010, he became one of the only two Brazilians to have received this honor thus far. He published an article entitled The China-Latin America Relationship Is a Model of Mutual Benefit in the People's Daily in July 2014, in which he stated, "China has established a close partnership with Latin America, although they are thousands of miles apart. This is of great referential value for promoting world peace and balanced development."

Shortly after his story was told by Xi Jinping in his speech, Carlos Tavares published his new book about China-Dois Temaspara Dilma: China e Portos. This book shows the achievements of China's reform and development in recent years and introduces China's policy of opening up. At the publishing ceremony of the book, Carlos Tavares specially wore a tie covered with Chinese seal characters and stated, "China now is one of the most important economies in the world and is Brazil's largest trading partner. But most Brazilians do not understand China at all or have only a one-sided understanding of it, and some even have a prejudice against the country. In fact, China has been developing rapidly, and a lot the experience it has accumulated is worth learning by Brazil."

"China needs to know more about the world, and the world also needs to know more about China." This was what Xi wanted to express through the story of the "Brazilian with a Chinese heart." How can one really know China? In Xi's view, "It takes a good deal of effort to know China, 
and simply visiting a place or two is not really enough." To be open and inclusive, China should tell "Chinese stories" well, and it also needs more people to approach it, to know it, and to promote it. The "Chinese stories" need to be told not only by "me" but also by "you", and by everybody. Only in this way will we be able to help people remove their "blinders" and see the real China and enhance the understanding among the states and between the peoples.

\section{The Arabian Restaurant in Yiwu}

Due to the rapid development of China-Arab relations, the peoples of both nations are closely linked by their destinies. In Zhejiang Province where I used to work, there is a Jordanian businessman named Muhamad who runs a genuine Arabian restaurant in Yiwu City, where many Arab business people gather. Muhamad brings genuine Arabian cuisine to Yiwu, and in exchange he has achieved business success in this prosperous Chinese city, married a Chinese woman, and settled down in China. Integrating his own goals with the Chinese dream of happiness, this young Arabian man has attained a marvelous life for himself through his perseverance, which embodies a perfect combination of the Chinese and Arab dreams.

- Promote the Silk Road Spirit, Strengthen China-Arab CooperationSpeech at the Opening Ceremony of the Sixth Ministerial Conference of the China-Arab States Cooperation Forum

(June 5, 2014).

\section{Commentary}

The young Jordanian Muhamad enjoys a great reputation in Yiwu's foreign business circle. His wife Liu Fang is from Anhui Province, China. After coming to China for the first time and getting a job in an Arabian restaurant in Guangzhou, he began to appreciate China, and he was happy to have met Liu Fang, a sunny and open-hearted girl from Anhui who worked with him in the same restaurant. In 2001, Muhamad married Liu Fang and became a full-fledged son-in-law of China. He took over an Arabian restaurant that his uncle opened in Yiwu in 2002 and renamed it “花”, the implied meaning of which is the flower of happiness and peace. He even designed a white flower as the logo of his restaurant. 
As a world-renowned international trade city, Yiwu frequently trades with Arab countries, and its commodities attract a constant stream of Arabian businessman. In 2005, the Ministry of Public Security authorized Yiwu City to issue visas and residence permits directly to foreigners. As one of the more than 4,000 Arabian merchants who live in Yiwu, Muhamad now has his own trading company. His two sons are at primary school in Yiwu and can speak fluent Chinese. He says he lives happily and has made a lot of friends in China, and he intends to buy a house in Yiwu to settle down there.

So many Arabian businessmen gather in Yiwu because, as locals describe it, Yiwu has reconstructed the Silk Road, and its people are quite inclusive and enthusiastic. Traveling in Yiwu, one can come across foreigners speaking different languages, in the International Trade City or in the Huangyuan Garment Market or in Binwang Market. Yiwu's growth from a commodity distribution center to a trade base of businessmen can be attributed to its inclusiveness, and such inclusiveness pushes China to achieve one success after another.

"Gold lucky birds, silver lucky birds, fly here and there, and finally to Yiwu." These are lyrics from a ballad widely circulated in Yiwu. Having begun "exchanging sugar for chicken feathers," the open, market-oriented, and inclusive city of Yiwu has become a "world supermarket" that offers a wide range of products. In addition to "selling to the world", Yiwu also "buys from the world." Yiwu Import Commodity Pavilion has imported an accumulative total of over 55,000 categories of commodities from over 100 counties and regions all over the world. Since 2014, Yiwu's exports to Arab countries have accounted for more than half of its total exports. Every year, more than 100,000 Arabian businessmen come to Yiwu for procurement, and tens of thousands of Arabs want to settle down in Yiwu to realize their dream of life.

Dreams are universal language without barriers. Xi Jinping has noted on many occasions that the Chinese dream is intrinsically interlinked with the world's dreams and the dreams of people around the world: "The dream is also about having more economic vibrancy, free trade and investment facilitation, better roads, and closer people-to-people exchanges. Moreover, the dream is about ensuring greater security and prosperity for the people and giving children a better environment in which to grow, work and live." At the Opening Ceremony of the Sixth Ministerial Conference of the China-Arab States Cooperation Forum, through the story about the Arabian restaurant in Yiwu, Xi Jinping demonstrated that the realization of 
the Chinese dream will bring the world peace, not turmoil, and that it will bring opportunities, not threats.

Proposing the Chinese dream, Xi Jinping looks forward to the Asian dream and the Asia-Pacific dream, which echo the American dream and the European dream. According to Xi, the Chinese dream is never closed or isolated, but it is interlinked with dreams of people around the world such as the American dream. Dreams are "like seeds under the ground. They must grow and sprout to embrace the sunshine." Muhamad's Chinese story is just a link in the interlinked dream that arises from openness and inclusiveness, mutual learning and mutual benefit.

\section{A Half-Century Journey Seeking His Mother}

Back in the late 1940s, a young Chinese man working in Xinjiang met a pretty girl named Valentina at a local hospital. They fell in love, got married, and had a child. However, due to the political climate and for other reasons, Valentina returned to her home country when their son was only 6 years old. When the boy grew up, he tried all means to find his mother but to no avail. In 2009, at the age of 61 , he finally found out that his mother was living in Almaty. He visited his 80 -year-old mother there and took her to China for a sightseeing tour. This happy family reunion, although overdue for half a century, is a strong testament to the friendship between our people.

- Promote Friendship Between Our People and Work Together to Build a Bright Future-Speech at Nazarbayev University (September 7, 2013).

\section{Commentary}

This transnational love story began toward the end of the 1940s when $\mathrm{Li}$ Yuankang's father, Li Huaiyu, who worked in Xianjiang, met his mother, Valentina, who worked at a local hospital. The young boy and young girl from different counties fell in love and then married and had a child. In 1954, due to social and political pressures, Valentina returned to her home country with their daughter, leaving 6-year-old Li Yuankang in China. Li Yuankang said, "Mom, sister, don't cry. Dad and I will be back in a week." The parting scene lingered in his memory for more than a half-century. 
The flavors of the bread, milk, and sausage that his mother prepared for him in his childhood and the old watch and toy carriage he asked for from his mother on parting became the one and only refuge for him to bear his yearning for her.

In the 1980s, with the death of his father, Li missed his mother even more. Every time an acquaintance was going to Russia or a nearby commonwealth of independent states, he asked the acquaintance to take the information he had to help him find his mother to the destination. In the winter of 2007, one of his friends sent his information to a relative-seeking TV program called "Wait for Me", which was produced by RUTV, the Russian state TV station. Fortunately, the staff of the program found a piece of information from Kazakhstan that highly corresponded with Li's. It turned out that his mother Valentina was also seeking her son.

In September 2009, the program “сколько лет сколько зим" (Long Time Ago) of the CCTV Russian International Channel and "Wait for Me" jointly provided a cross-border live video broadcast. On December 27, Li Yuankang participated in the program arranged by CCTV in Moscow, and at the same time, his mother and sister, who were living in Almaty, Kazakhstan, also attended it on invitation. In the telestudio, as his mother came into his view, although she no longer looked as young as she was on their parting day, he immediately dropped to his knees, knelt before her, and embraced her legs, with tears coursing down his cheeks. His mother was stooped with age, and her skin was now wrinkled by time.

This touching ending was attributed to the increasingly closer peopleto-people and cultural exchange between China and Kazakhstan. Peopleto-people exchange now results in 500,000 visits per year, and it includes 12 pairs of sister provinces. Prefectures and cities have been connected, and our peoples connect with each other like "relatives". After learning about Li Yuankang's story from Xi Jinping, almost all Li Yuankang's relatives and friends called him to congratulate him. He said he felt glad and warmed by the fact that President Xi referred to him in the speech: "It can be said that the family affection between me and my mother and sister who live in Kazakhstan symbolizes the friendship between our two nations."

"The history of a land is the history of its people." In the speech at Nazarbayev University, through the reunion story of the long-separated family, Xi Jinping showed the profound China-Kazakhstan friendship, family-like affection between the two peoples, and the cultural heritages of the two counties, making the two peoples closer. 
China and Kazakhstan are neighbors as close as lips to teeth. Their exchange can be traced to the ancient Silk Road, and on the exchange will be continued in the Belt and Road Initiative. Before coming to the story of "a half-century journey of seeking his mother", Xi stated, "Shaanxi, my home province, is at the starting point of the ancient Silk Road. Today, as I stand here and look back at that episode of history, I can almost hear the camel bells echoing in the mountains and see the wisps of smoke rising from the desert. It has brought me close to the place I am visiting." From the perspectives of history and reality, respectively, the memory of Xi's hometown at the starting point of the ancient Silk Road and Xi's sympathy for Li Yuankang's half-century journey of seeking his mother are combined to communicate that Xi sincerely cherishes the China-Kazakhstan friendship.

\section{"PAnda Blood" Donated to Chinese Friends}

You may know that the Rh-negative blood type is called "panda blood" in China because it is as scarce as a panda. It is very hard for Rh-negative patients to find a compatible blood source. Ruslan, who studied at Hainan University in China, happens to be Rh-negative. Since 2009, he has been donating blood twice a year, helping to save Chinese patients of his same blood type. When praised by his Chinese friends, he simply said, "I feel this is what I should do. It is my duty to help others."

- Promote Friendship Between Our People and Work Together to Build a Bright Future-Speech at Nazarbayev University (September 7, 2013).

\section{Commentary}

"Panda blood" refers to the Rh-negative blood type, which is as scarce as a panda. It is very difficult for Rh-negative patients to find compatible blood sources in China. The RH blood group system is the second most important blood group system of human beings, after the ABO blood group system. It is usually indicated by an Rh-positive or Rh-negative suffix to the $\mathrm{ABO}$ blood type. Most of the people among us are Rh-positive. Among Europeans and Americans, 15\% of the people are Rh-negative, while among Asians, only $0.3-0.4 \%$ are. 
The protagonist in this story, Ruslan, who studied at Hainan University in China, is one of them. He enrolled at Hainan University in 2009. He said, before going to the university, he rarely donated blood in his home country because he was young then, and he did not realize that he had a scarce blood type until he came to China. In China, he became involved in voluntary blood donation following the lead of his classmates. He donates blood twice per year so that his "panda blood" can help meet the urgent needs of Chinese patients. Because of this, he was acclaimed by the Chinese President as an envoy of friendship between the two countries. Ruslan said it was a great honor and stated, "I am very happy to further contribute to the friendly exchanges between China and Kazakhstan!"

Ruslan's story in China is the epitome of China-Kazakhstan friendship. According to Kazakhstan statistics, the number of Kazakhstan students studying in China has already reached 11,200, and many of them are the "envoys of friendship between China and Kazakhstan" praised by Xi Jinping. Kazakhstan sisters Myra and Naia are students of Xi'an Jiaotong University. When they had just arrived in China from Kazakhstan, they "did not understand Chinese at all." However, today they are "familiar with Xi'an even more than the cities in their homeland, so that sometimes they have to ask for directions when they return to their hometown." There is another "senior Kazakhstan student" who studied in China and can speak Chinese fluently-Karim Masimov, who was appointed by the Prime Minister of Kazakhstan 2014. Similarly, an increasing number of Chinese are now traveling to Kazakhstan. With superb skills and a conscientious attitude, Wang Kun and Lan Zhixue, two technicians from Ningxia, China overcame obstacles one by one and solved major technical problems for the Atyrau Refinery, one of Kazakhstan's top three refineries. This has become a favorite local tale. When they returned to their homeland, the Kazakhstan party organized a grand farewell ceremony at the airport. In today's interconnected world, such "envoys of friendship" between China and Kazakhstan can be compared to scenic sights that move between the two nations.

Young people are the mainstay of friendship between our people. The common interest and ideals they hold for life bring them together in true friendship. The story of "panda blood" not only manifested the mutual affinity and friendship between the Chinese people and the Kazakhstan people but it also expressed Xi Jinping's expectation that the young people of the two countries would undertake the responsibility of the envoy of 
friendship and contribute their youth and strength toward the development of the comprehensive strategic partnership between their home countries.

In the speech, Xi Jinping presented to the young people the words of the great Kazak poet and philosopher Abay Qunanbayev: "The world is like an ocean and our time is like strong wind. The waves in the front are the elder brother while those behind are the younger brother. Driven by wind, the waves from behind constantly press on those in the front. This has been the case since ancient times." From Li Yuankang's "half-century journey of seeking his mother" to "donating panda blood", the two touching stories involving the Chinese and Kazakhstan people reveal a truth: "The key to sound relations between states lies in amity between the people," while the key to amity between the people is based on friendly exchanges between the nations' young people.

\section{The Feeling of Taking All the Gold Medals}

I am a football fan myself. Chinese football players have worked very hard, but so far, our national team has qualified for the World Cup only once. It was Mr. Bora Milutinovic who led the Chinese football team to the World Cup and who also happened to be the head coach of Mexico's national football team.

I have heard an anecdote: A Mexican sports official once asked the head of the Chinese diving team, how do you feel taking all the gold medals? Two years ago, our Mexican friends had a taste of such success. With the help of Chinese coaches, Paola Espinosa, known as the "princess of diving" in Mexico, and her teammates swept all titles in the eight diving events of the 2011 Pan-American Games. We hope that the Mexican diving team will get more gold medals in the future and that our two countries will win even more "gold medals" in cooperation.

- Seek Common Development to Create a Better Future-Speech at the Senate of Mexico (June 5, 2013).

\section{Commentary}

The "magic football coach" Bora Milutinovic is a man who lives in the memory of both Chinese and Mexican football fans because of the miracles he created. 
At the 1986 Mexico World Cup held in Mexico, Milutinovic led the "straw hat legion" of Mexico to the quarterfinals, and his "Team 1986" gave a classic performance in the football history of Mexico. In addition, at the 2002 FIFA World Cup that took place in South Korea and Japan, he led his "Team 2002" to a classic record of Chinese football. On October 7, 2001, scoring a goal through team member Yu Genwei, the Chinese football team defeated Oman at Shenyang Wuli River Stadium, qualifying China for its first appearance at the World Cup. As the only coach who has led five different teams to the World Cup, Milutinovic, a Serbian, was rated by the Global Times as one of 60 foreigners who have influenced China. The Mexicans gave praise: "This is another miracle created by Milutinovic," who first made a name for himself in Mexico, and believe that "It is of great significance to the World Cup itself" that China, as the world's most populous country, made its first appearance in the World Cup finals.

With regard to diving, few people in China know that, in addition to China's "Dream Team", there is also a "Mexican Dream Team"- the Mexican diving team. This team swept all eight gold medals for diving events at the 2011 Pan-American Games, with its "princess of diving" Paola Espinosa taking half the medals. The person who led Mexico to taste the success of taking all the gold metals was Ma Jin, a sports coach designated by the Chinese government. As a member of the Chinese coaching team to aid Mexico, she understood the responsibilities of managing the divers' training in her spare time, equipment deployment, contest arrangement, and even the divers' daily lives. The mentoring relationship between Ma and Espinosa began with Espinosa's defiance against Ma. However, with her improvement in performance, she later treated the coach as someone she greatly trusted. The "princess of diving" and her boyfriend even presented a birthday gift to Ma- a necklace pendant with a pattern of a boy and a girl. They hoped that Ma would regard them as her own children. As Ma became famous in Mexico, she was honored as an envoy of friendship between China and Mexico. She was met by the former Mexican presidents many times, and the Mexican government even awarded her the Order of the Aztec Eagle, the highest honor Mexico awards foreigners in the country, in recognition of her contribution to the Mexican diving cause and the promotion of friendship between China and Mexico. Ma believes that diving is one of the highlights of the sports exchange between China and Mexico and that the development of the friendship between the two countries will provide a better environment for and further facilitates her sports exchange activities in Mexico. 
Sharing the stories of Milutinovic leading the Chinese football team to the World Cup and the Chinese diving coach helping the Mexican divers win gold medals, Xi Jinping conveyed the idea that "unity means strength, while isolation means weakness." In today's world, no country can develop without interdependence, and only cooperation can push us to mutual benefit and win-win results.

After telling this story, $\mathrm{Xi}$ Jinping shared an old Chinese saying: "A single flower doesn't make spring, while one hundred flowers in full blossom bring spring to the garden." Xi then quoted the Mexican poet, Alfonso Reyes: "The only way to be successfully national is to be generously universal." What does taking all the gold medals feel like? We can all obtain a sense of that through win-win cooperation. Developing together is much better than developing by oneself. By relaying these sports stories, $\mathrm{Xi}$ Jinping illustrated this idea. As he said, "By working closely together, the countries will gain far more than what their combined strengths could produce."

\section{A Young Chinese Couple's African Honeymoon}

Let me tell you a story of a young Chinese couple. When they were kids, both the boy and the girl got to know Africa from Chinese TV programs and have since been captivated by this continent. Later, they got married and chose Tanzania as their honeymoon destination. So, on their first Valentine's Day after the wedding, they went there and backpacked across this country. They were overwhelmed by the hospitality and friendship of the local people and the magnificent savanna of the Serengeti. After the couple went back to China, they posted what they saw and heard in Tanzania on their blog, which received tens of thousands of hits and several hundred comments. This is what they wrote in their blog: "We have completely fallen in love with Africa, and our hearts will always be with this fascinating land." This story speaks to the natural feeling of kinship between the Chinese and African people. As long as we keep expanding people-to-people exchanges, the friendship between our peoples will take root deeply and continue to flourish.

- Trustworthy Friends and Sincere Partners Forever-Speech at the Julius Nyerere International Convention Center (March 25, 2013). 


\section{Commentary}

The young couple, Mr. Chen and Ms. Li, in President Xi's speech, is fellow travel enthusiasts. They both yearn for "poetry and the far afield" and met each other on a trip. Their trip to Africa adds an exotic color to their honeymoon. On February 14, 2010, the Lunar New Year's Day in China, they embraced their second morning in Africa, and the day was also the first Valentine's Day after their wedding.

Why did they select Africa as their honeymoon destination? Mrs. Li said that she had enjoyed watching CCTV's program Animal World in her childhood, and Africa impressed her as a pure land where man and nature live in harmony in a way that could purify one's soul. The films Lion King, Madagascar and Out of Africa as well as documentary films about Africa produced by the $\mathrm{BBC}$ conjured images of rambling across the continent. Coincidentally, her husband had the same dream. Thus, they decided to make their long-standing dream come true in Tanzania during their honeymoon.

Mrs. Li shared with the media the amazing and moving moments they experienced on the trip. They ran with the animals in the Great Migrations, they searched for lions and cheetahs at the craters, they witnessed the beauty of the equatorial snow mountains from the "roof of Africa", and they even swam with dolphins in the Indian Ocean. However, what impressed them most were the African friends with whom they became acquainted on the road. For example, there was a taxi driver who not only patiently helped them to find a hotel but also helped them carry their baggage in the rain until he was drenched. There was a tour guide who led them on a walk a great distance so that they could appreciate the wild animals without invading the animals' territories or disturbing them. With their simplicity, kindness, and love for nature, the African people build a bridge to the heart of the Chinese people.

Tourism is an important link in the friendship and cooperation between countries and Africa is the destination of China's outbound tourism with the fastest growing market share. According to the Annual Report of China Outboard Tourism Development 2015 issued by the China Tourism Academy, Africa seized $9.4 \%$ of the Chinese outbound tourism market in 2014 , showing a year-on-year growth of $80.9 \%$ as the fastest growing destination in recent years. Meanwhile, statistics show that the number of Chinese tourists visiting Kenya to watch the Great Migrations of animals 
during August and October each year has already surpassed tourists from Europe and the US.

Tanzania was the first stop of Xi Jinping's state visit to Africa as Chinese President. One hearing this, Tanzanian President Kikwete said, "I could hardly believe my ears." When talking about China's "affinity” for Africa, Xi shared the Chinese young people's story of yearning for, exploring in, and falling in love with Africa. This is a convincing demonstration of ordinary Chinese people's pure affection for Africa, and it is also a contemporary episode in the continuing epic of friendly China-Africa exchanges.

$\mathrm{Xi}$ is also an important witness of China-Africa friendship. As early as his youth, he knew well the sincere exchanges between the first-generation leaders of new China-Mao Zedong, Zhou Enlai, and others-and the African statesmen of the older generation, and he has paid seven visits to Africa. Through the young couple's story, he hoped to communicate that there is natural feeling of kinship between the Chinese and African peoples; as long as we continue to expand people-to-people exchanges, the friendship between our peoples will grow deep roots and continue to flourish.

Open Access This chapter is licensed under the terms of the Creative Commons Attribution-NonCommercial-NoDerivatives 4.0 International License (http:// creativecommons.org/licenses/by-nc-nd/4.0/), which permits any noncommercial use, sharing, distribution and reproduction in any medium or format, as long as you give appropriate credit to the original author(s) and the source, provide a link to the Creative Commons license and indicate if you modified the licensed material. You do not have permission under this license to share adapted material derived from this chapter or parts of it.

The images or other third party material in this chapter are included in the chapter's Creative Commons license, unless indicated otherwise in a credit line to the material. If material is not included in the chapter's Creative Commons license and your intended use is not permitted by statutory regulation or exceeds the permitted use, you will need to obtain permission directly from the copyright holder.

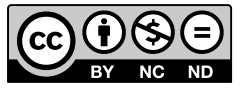

